Western Washington University Western CEDAR

\title{
Fugitive Teacher Education: Nurturing Pedagogical Possibilities in Early Childhood Education
}

Anna Lees

Western Washington University, anna.lees@wwu.edu

Verónica N. Vélez

Western Washington University, Veronica.Velez@wwu.edu

Follow this and additional works at: https://cedar.wwu.edu/woodring_dei

Part of the Education Commons

\section{Recommended Citation}

Anna Lees \& Verónica N. Vélez (2019) Fugitive Teacher Education: Nurturing Pedagogical Possibilities in Early Childhood Education, The Educational Forum, 83:3, 309-324, DOI: 10.1080/00131725.2019.1599658

This Article is brought to you for free and open access by the Woodring College of Education at Western CEDAR. It has been accepted for inclusion in Woodring Scholarship on Diversity, Equity, Inclusion by an authorized administrator of Western CEDAR. For more information, please contact westerncedar@wwu.edu. 


\title{
Fugitive Teacher Education: Nurturing Pedagogical Possibilities in Early Childhood Education
}

\author{
Anna Lees and Verónica N. Vélez \\ Woodring College of Education, Western Washington University, Bellingham, \\ Washington, USA
}

\section{Abstract}

This article argues for the necessity of fugitivity in teacher education to interrupt and subvert the current regime of standardization in public education. Centering the voices of teachers and teacher candidates, this qualitative case study explores the importance of unsanctioned spaces for destabilizing co-optations of multiculturalism and social justice in teacher education. Findings suggest conceptual and practical possibilities for developing critical curricula and pedagogies in early childhood teacher education that work towards a postcolonial state.

Key words: early childhood education, fugitivity, social justice, teacher education.

As women of color faculty at a state university in the Pacific Northwest, we began our careers as teacher educators deeply concerned about the impact of standardization in U.S. prenatal-through-grade-12 ( $\mathrm{P}-12)$ and in teacher education. With professional experiences as an early childhood educator and a school-based grassroots organizer, we witnessed firsthand how neoliberal agendas in educational policy translated into a climate of frustration among teachers, students, and families. Our journeys have led us to consider how standardization mediates our efforts to foster critical and land-based pedagogies in the preparation of early childhood educators and examine the impact of such efforts on current teachers and teacher candidates. 


\section{Lees and Vélez}

Given our shared interests, we pursued inquiry to explore what is needed in teacher education to interrupt and subvert the current regime of standardization in public education. Using a case study of teachers, teacher candidates, and teacher educators at a public liberal arts university in the U.S. Pacific Northwest, we investigated the importance of unsanctioned spaces for destabilizing co-optations of multiculturalism and social justice in teacher education. In particular, we explored how an organic, activist, and student-led learning community through an academic minor in social justice education (SJE) merged with an early childhood education (ECE) degree program to propel a vision of teacher education that wrestles with economic inequality and poverty, corporate and state power, settler colonialism and imperialism, White supremacy, and struggles over place and territory.

The SJE minor was initiated by students in 2013 concerned with a lack of critical conversations on campus about the impact of current neoliberal reforms in schools and the need to center social justice as a driving framework in the preparation of teachers (Apple, 2011; Au, Bigelow, Burant, \& Salas, 2005; Cochran-Smith, 2004). Although it formed into an academic minor, students insisted on driving its curricular and programmatic vision toward a more radical imaginary of education, rejecting university logics of meritocracy, competition, standardization, and otherwise colonial projects and aims. In the process, they used the minor as a platform for building an unsanctioned learning community that would drive student-led movement-building across campus for ethnic studies, environmental justice, women, gender and sexuality studies, and Indigenous studies. Alongside these efforts, an ECE degree program with teacher certification was deepening its sustainable, mutually beneficial partnerships with diverse schools and communities to offer candidates a fieldbased teacher education, allowing for opportunities to practice their teaching and employ

community-based pedagogies and student-centered, inquiry-based curricula with structured support (Lees \& Kennedy, 2017). As students crossed from the minor into the ECE program and vice versa, an opportunity emerged to build networks, plot radical reform efforts, and scheme pedagogical strategies typically unseen, and often refused, within sanctioned teacher education programs in higher education.

Our data and analysis draw from the experiences of current and aspiring teachers, to describe how they have connected critical theories from their preparation in the SJE minor with their work in classrooms and with communities to serve young children and families. We consider the following-How do beginning teachers work to surpass an age of standardization through a model of fugitive teacher education, where sanctioned and unsanctioned spaces meet to create new possibilities of transformation, particularly in ECE? We offer an overview of an emerging program structure that interweaves the SJE minor curriculum into the sequence of courses toward an ECE degree with teacher certification and examples of course content including the use of critical and decolonizing theories (Smith, 2013; Tuck \& Yang, 2012) in on-campus and field-based experiences. Based on our findings, we suggest both conceptual and practical possibilities for developing critical curricula and pedagogies in early childhood teacher education that work toward a postcolonial state. We define the term postcolonial not as a period of time, but rather "an aspiration, a hope, not yet achieved" (Battiste, 2004, p. 1). 


\section{Resisting Standardization in Early Childhood Education Through Fugitivity}

\section{Literature Review and Theoretical Perspectives}

Given current polarized debates concerning educational equity and issues of human rights, professionals in teacher education are discussing how to best prepare teachers to serve the diverse and holistic needs of children and families. These discussions are everpresent in ECE. A myriad of pressures around policy and practice in ECE impact the work of teachers in classrooms with young children. Accountability measures stemming from No Child Left Behind, state adoption of Common Core State Standards (CCSS), and policy briefs going back to A Nation at Risk (National Commission on Excellence in Education, 1983) and beforehand have impacted how early childhood teachers are positioned to prepare young children for the "academic rigor" needed to preserve the state of our nation in a global economy.

\section{Standardization in Early Childhood Education}

The increased accountability measures impacting ECE curriculum and instruction have a wider reach than learning standards and assessments alone. The era of neoliberal standardization of education has impacted the ways in which educators interact with standards and how routines, expectations, and classroom community is or is not created (Noddings, 2005). The notion of teaching through love, with aims toward happiness, has been associated with children developing into socially conscious adults (Haslip \& Gullo, 2018; Noddings, 2005), but is not emphasized in standards driven curriculum and assessment. Thus, teachers are torn in meeting the complex needs of children, families, and communities. They understand that loving children alone is not enough and they find little value in improved test scores (grounded in settler-colonial notions of success) as an end goal.

Responding to the expressed challenges of ECE professionals to appropriately meet the developmental needs of children, within the context of community, the National Association for the Education of Young Children (NAEYC, 2015) released a brief considering how the CCSS can align with developmentally appropriate practice (DAP). While the brief argues that CCSS are supportive of DAP, NAEYC (2009) posited, "standards overload is overwhelming to teachers and children alike and can lead to potentially problematic teaching practices" (p. 4), including an overemphasis on discrete skills and whole group instruction. The NAEYC position statement makes a clear case for play as the most appropriate curriculum for children birth-through-grade-three; and while they support the CCSS in allowing for DAP, we put forth a more complex reality in what follows.

We push back on the notion of high stakes accountability measures in ECE and argue that the prospect of losing play and community approaches to teaching and learning is incredibly high stakes. Haslip and Gullo (2018) documented the loss of arts and exploratory play in ECE curriculum in favor of math and literacy standards emphasized in CCSS. Their research concluded that children from communities historically underserved by U.S. schools have higher success in high school and college academics, and maintain employment in adulthood, when arts learning is a central part of their educational experience. Additionally, a skills-based curriculum has the potential to prepare children for an economically 
successful future, but forgoes commitments to social justice. Holistic education prepares children to engage as socially conscious adults (Haslip \& Gullo, 2018). As ECE classroom teachers face increased accountability, teacher education programs mirror the neoliberal standardization of PK-12 education (Cochran-Smith, 2004). In this complex reality of hyperaccountability and a social context in need of radical change, centering social justice frameworks in ECE teacher education is essential (Apple, 2011).

\section{Centering Social Justice Frameworks and Pedagogies in Early Childhood Teacher Education}

Defining "social justice" in teacher education must contend with the shifting terrain on which current movements for change in education are being waged. As universities generally, and colleges of education specifically, claim to value "diversity and social justice" while concurrently punishing and criminalizing students and faculty at the forefront of these efforts, what possibilities still remain for linking teacher education and social justice, particularly in ECE? As neoliberal multiculturalism reorders the current regime of the academy, what radical shifts must be undertaken within teacher education to meet the call to prepare teachers as activists and advocates of justice now and into the future (Cochran-Smith, 2004)?

Preparing critical and socially just teachers has also been established specific to the field of ECE (Heineke, Kennedy, \& Lees, 2013). Situating the relationship between pedagogy, curriculum, and society, this body of work foregrounds the political context in which teachers are being prepared to instruct the youngest in society. Grounding early childhood teacher education within deep commitments to social justice requires teacher educators to (re) examine how candidates are prepared to serve children within a wide range of community contexts. This requires a move beyond campus-based education and toward meaningful engagement with teachers, families, and communities as co-teachers. Such a framework, grounded in mutual benefit and reciprocity, challenges meritocratic aims fundamental to the standardization of schooling. By disrupting the notion of university faculty as the sole experts in teacher education and collaborating deeply with and in community, teacher education programs recognize the complexity of experiences that must be addressed in preparing teachers to serve all children (Lees \& Kennedy, 2017). Centering multiple stakeholders mirrors the reality of early childhood classroom teachers as part of an extensive network of professionals, families, and communities committed to the development of young children (National Association for the Education of Young Children, 2010). While the need for quality early childhood teacher education is clear and research has put forth models for developing social justice teacher education programs, little is known about the ways in which teachers and teacher candidates make sense of preparation programs in relation to their teaching.

\section{Fugitive Teacher Education: A Theoretical Framework}

To situate this study, we used a framework of decolonization (Smith, 2013; Tuck \& Yang, 2012) and fugitivity (Harney \& Moten, 2013; Stovall, 2018) to examine a third space (la paperson, 2017) within a teacher education program at a public university. We used decolonization theories to understand how teachers, teacher candidates, and teacher educators within this space disrupted the settler-colonial construct of higher education to foster critical pedagogies toward Black, Brown, and Indigenous futurities (Tuck \& Gaztambide-Fernández, 
2013). Drawing on Harney and Moten's (2013) notion of fugitive planning and la paperson's (2017) hope of a third university we dissected the intersection of two programs with shared commitments of decolonization in a whitestream college of education. We questioned the possibility of change within the institution so soundly structured in colonial ideals and examined the experiences of teachers and teacher candidates working to uphold dreams of a postcolonial future in their work with young children and families. With fugitivity, we searched for the spaces within the intersections of the ECE program and the SJE minor that fostered participants' capacity to work against the settler-colonial and neoliberal ideals that drive contemporary schooling.

We theorize fugitivity within teacher education as an intentional move to generate critical theoretical and material spaces wherein aspiring teachers openly analyze the relationship of schooling to the state, dare to imagine other educational and pedagogical possibilities, and wrestle collectively as teachers toward a postcolonial future. We argue that fugitivity necessitates the creation of unsanctioned spaces that are beyond the reach and control of university administration or other state-controlled institutions. These spaces are not new and have existed for generations to propel movements like, for example, ethnic and women's studies. In the preparation and support of teachers, we have seen these spaces thrive outside of academia and in grassroots, community-based learning communities like the Institute for Teachers of Color and Teachers for Social Justice.

Emerging literature is quick to note that fugitive spaces are imperfect but necessary (Stovall, 2018). A fundamental contradiction is raised about what it means to operate within schooling toward liberatory ends (Freire, 1973; Giroux, 2003). Fugitivity moves more intentionally toward what's possible by asking, "given the constraints and foundations of statesanctioned violence as 'schooling,' can education happen in the institution commonly known as 'school'?" (Stovall, 2018, p. 53). Here, Stovall reclaims "education" as critical for disrupting the function of schooling that seeks to perpetuate and maintain society's existing power relations. He goes on to argue that an education, radically defined, can become the political exercise that ends repression (Stovall, 2018).

This study shows that fugitivity, and the unsanctioned spaces it generates and on which it relies, can exist within higher education but must position its aims beyond that of transforming teacher education programs, given the university's continued investments. While we believe the merger of the two programs that are the focus of this study generated new possibilities for early childhood teacher education, its goals were shaped by community needs, not university ones. Framing our findings from a fugitive standpoint allowed us to assess the extent to which teacher education programs can destabilize neoliberal co-optations of social justice and what's still needed outside of such programs to support the development of teachers with radical sensibilities and commitments.

\section{Methodology}

To collect, analyze, and interpret data for this study, we partnered with current teacher candidates and alumni teachers in a qualitative study to understand the unique and complex lived experiences of the participants. The qualitative design allowed us to share findings of this research through thick, rich descriptions (Merriam \& Tisdell, 2015) that paint the 
complex picture of the current reality of teacher candidates and teachers in an era of standardization. We also offer our insights as teacher educators to provide a more intimate portrait of the program structure that interweaves the SJE minor curriculum into the sequence of courses toward an ECE degree with teacher certification. We used single case design (Yin, 2017) to uncover how beginning teachers work to surpass an age of standardization through a model of fugitive teacher education. The unsanctioned learning community at the intersection of the ECE degree program and the SJE minor was the subject of this case, featuring the impact of this critical community on participants' teaching practices. This partnership was purposefully selected as the case in this study due to (a) our intimate connection to both programs as faculty and program director and (b) the uniqueness of this partnership situated across separate departments within the college of education. In this study, our case centered on the experiences of candidates and alumni teachers within the overlapping programs in which they prepared or are currently preparing for their work as future teachers.

\section{SJE Minor}

The SJE minor, directed by coauthor Verónica Vélez, integrates theory and practice to equip students with the skills and knowledge for understanding the complex relations of culture, power, systems of oppression, and movements for social justice in connection to schools. In less than five years, the SJE minor went from 20 students to over 350, attracting the very students higher education is prioritizing in both recruitment and retention. The popularity of SJE responds to a multifaceted failure of educational systems for a generation of youth who are trenchantly seeking critical lenses, genealogies, and theoretical frameworks through which to interpret their experiences. Responding to deep needs for academic, social, emotional, and intellectual support, the minor has emerged to infuse agency and possibility for students working toward social change. In the process, it has come to fill a deep institutional vacuum, responding to needs-curricular and otherwise-for which the most underserved students in academia on a national scale are calling.

Programmatically, the SJE minor employs popular education and community-based strategies to develop student-centered curricula. In fact, it was students who called for the creation of SJE. Students were concerned about the lack of critical conversations on campus about the impact of current neoliberal reforms in schools and organized to push for a more radical vision of social justice as a driving framework in the preparation of teachers. Since then, SJE students have been actively involved in all aspects of the design and revision of the minor and their investment in the day-to-day work of the program has been central to its success.

\section{Early Childhood Education Program}

The ECE program includes an academic major of ECE and a sequence of professional certification courses that lead to a bachelor's degree in prenatal-through-grade-three education and teacher licensure $\mathrm{K}-3$. The coursework offers a combination of theory, methods, and field experiences in ECE settings serving infants and toddlers, pre-primary, and primaryaged children. Additionally, the program emphasizes collaboration with families and com-

munities in culturally and linguistically diverse settings and supports candidates' use of inquiry-based and decolonizing pedagogies. Over the past 2 years coauthor Anna Lees, 
who is also ECE/SJE program faculty, collaborated with the SJE director and ECE program faculty to integrate key tenets of the SJE minor into the ECE coursework and practicum experiences. These connections deepened the explicit commitments to social justice, critical pedagogies, and decolonization within the program continuum and partnerships. Candidates gained opportunities to focus their inquiry around land, water, and arts-based education and considered the complexities of teaching for social justice within a university situated on the ceded territories of tribal nations. Additionally, the program fosters connections between candidates' understanding of course content as it relates to their lived experiences and interactions with children and families in their own communities.

Within the ECE program continuum, aspiring teachers begin their field-based experiences from the beginning of their preparation and continue through degree completion. Candidates engage in a variety of learning settings including the campus childcare center, Head Start and state-funded preschool, private childcare and preschool, public school classrooms $\mathrm{K}-3$, bilingual Spanish programs, and tribal nation early learning centers. Within these settings, candidates complete a variety of practicum and field-based preparation courses focused on child development, environments, play and creativity, language and literacy methods, as well as a full-time internship experience in both preschool and primary $(\mathrm{K}-3)$. The participation in practicum and internship is grounded in long-standing partnerships between ECE faculty and school/community partners that strive to be sustainable and mutually beneficial.

\section{The Participants}

Participants for this study were drawn from a pool of teacher candidates and alumni teachers who completed or are currently enrolled in both the SJE minor and the ECE program under study. We interviewed a total of six participants, three alumni and three teacher candidates. Five of the six participants identified as women, and one participant identified as a queer man. Additionally, five of the six participants identified as first-generation college students and first-generation teachers of color. Each participant brought unique lived experiences that shaped their perceptions of teaching and teacher education. With a small sample size, and uniquely distinct identities among participants, we have chosen to report our findings through a collective voice, using "they/them" pronouns in order to preserve participant anonymity. Using qualitative research methodologies (Merriam \& Tisdell, 2015) and single case design (Yin, 2017) we conducted interviews with participants together as faculty within both programs. Data collection and analysis was grounded in our framework of decolonization and fugitivity. We also added our perspectives as women of color faculty and program leaders in ECE and SJE throughout our analysis.

\section{Teaching for Transformation}

Throughout the data, we uncovered examples of teachers and teacher candidates employing critical literacies with young children, facilitating inquiry projects around preschool children's relationships with the natural world, and teacher-led organizing with families and communities. Through these examples, we depict how fugitive teacher education can dismantle structures and standardization that demand educators teach in service to settler colonialism and White supremacy. Findings demonstrate that fostering fugitive spaces within teacher education programs is possible and promising in the work of educational 
reform, particularly in ECE. We frame these findings through five subthemes: (a) relationship and community building, (b) centering the whole child within family and community (c) living and learning in the in-between through unsanctioned networks, (d) nurturing fugitive futurities, and (e) navigating systems strategically. We close our analysis with implications for continuing to prepare radical educators.

\section{Centering Relationship and Community-Building}

Across our findings, each participant referred to the ECE/SJE programs as more than academic units, but rather as spaces grounded in relationships and community. They identified the moments when they met ECE/SJE faculty as critical in the trajectory of their development and contrasted these moments to other experiences in their education that did not have the same impact. The participants also shared experiences working with children; specifically, their goals in teaching the whole child and embodying community ways of knowing and being. In speaking of their experiences in ECE/SJE, a participant noted:

ECE and SJE are very student-centered and student-driven. It's very relationship based. They are really calming spaces. I never feel lost or alone. I know that ECE and SJE will love me through my challenges but also will be direct and blunt. You always help me strategize. Not a lot of other programs or faculty do this.

Building on understandings of education as a relationship-based experience, one participant discussed the importance of creating a classroom space where that work can emerge. They noted, "Once you set up an environment where you have relationships with them you can teach because they trust you." This participant consistently discussed the importance of relationships in teaching; interestingly though, they did not connect this work to meeting curriculum goals, rather as a precursor to beginning instruction. The participant connected their own learning through the ECE/SJE program:

Once I started becoming critically literate, I think I separated those worlds [ECE and SJE]. I had support from faculty, but I didn't seek that [social justice] support from them. I really relied on my peers and then once the [ECE/SJE faculty] came I really relied on her a lot. When she came, it was really eye opening for me to see that these two worlds [ECE and SJE] can collide.

This participant, who identified as an Indigenous person of color, depicted how connecting with a faculty member who had similar cultural values was important to their understanding of how social justice and ECE connected. When the participant could see themselves in the curriculum and trust the faculty, they were able to make deeper connections with the content. The participants also discussed a desire to engage more with families. One alumni participant shared that the district focused on how not to engage with families, they described, "We're trained not to email if a family has an emergency and told to avoid giving families your number. 'Don't have ice cream outside of school with a student.' There is so much restraint and people are so afraid of the community here that they might get a lawsuit." This contradicted the plan they shared to connect more closely with students' families: 
From 11-12, I'll have an hour where families are welcome to come in and see what we're doing. I felt so disconnected with my families and I think it's because they've had these teachers over the past four years who see them twice a year on conferences, so they don't see the value in connecting with a teacher. I want to embed the parents into my community.

Participants' depictions of centering their work in relationship and community was central to how they thrived as students. The participants separated their efforts of building genuine community in their classrooms from meeting curricular goals. As one alumni participant noted, "Outside of the curriculum we would have community circles and talk about racism and read about current events. Math and science seem separate. I want to weave everything together, so it doesn't feel like this community circle is super different than when we do math." The notion of building relationships connects explicitly with the next theme where participants discussed how they aspire to center the whole child in their teaching.

\section{Centering the Whole Child Within Family and Community}

All participants depicted unwavering commitment about serving children's holistic needs and viewing them as individuals within a greater network of family and community. They depicted commitments to foster children's academic growth and account for their complex experiences. As participants depicted their awareness of children as part of greater family networks, they also discussed how experiences in ECE/SJE prepared them to serve children's holistic needs:

I want the students I teach to know they matter, to see the wholeness of who they are. The main reason why ECE/SJE felt right for me is because that was me growing up. I didn't feel that I mattered because of how I was treated in school. I just don't want that pattern to repeat itself.

Participants discussed the challenges in centering the needs of the whole child in an era of standardization. One candidate shared, "I want to 'do right' by my kids but I have to worry about the standards. I don't yet know how to balance the standards with students' needs and being true to myself and my teaching practices." Other participants depicted centering children's needs as different from the school curriculum. In a powerful recollection, one alumni participant detailed how the school counselor, in opposition to her addressing the socioemotional needs of her students, threatened to deny services:

I keep a journal in my classroom for them to write in when they are frustrated. So the pushback from the counselor was that if a student is feeling suicidal they are more inclined to write it than to come up to me and say I'm feeling suicidal. And I said "OK, yeah I agree with you, they are more inclined to write it and what's wrong with that? If they feel more comfortable writing it then good! We should get them help!" And she said, "no your job is to educate. Your job is to teach them math, reading, writing, science, and social studies. You are not a counselor. You are opening gates that you should not be opening." And I thought, I don't agree with this. And the counselor told me that if something was to go wrong and a child wrote something like that, she would not deal with that issue because she had warned me. And I said, "consider me warned." 
Demonstrated through this quote, teachers working beyond standardized curriculum found themselves in spaces where they were explicitly threatened or punished for a perceived over-stepping of their role. In this instance, working to serve the holistic needs of children was viewed negatively. Thus, the participant is essentially told that the role of a teacher is bounded to instruction of sanctioned curriculum. The same participant went on to reflect about school culture around standards, "some teachers don't ever look at the standards and some won't teach outside of the standard."

Last, participants made it clear that centering children and families with the greatest needs would benefit the overall educational experience of the class. One participant stated, "Putting marginalized students at the forefront benefits everybody in the school. If you're doing culturally responsive teaching to support your students of color, it's going to support all of your students." Offering an example from practice, they shared,

The kids know what's happening in the world and they have opinions but no one is giving them space to talk about it. They know that racist things happen and they want to talk about it. So that's what I wanted to provide for them. A space to talk and read articles about what happened. I just want them to feel validated.

Collectively, the participants stressed the importance to seeing curriculum far beyond the limitations of state standards. Rather, they insisted on pedagogies that understood the experiences of children as embedded with family and community contexts. Building these strategies required the participants to establish collectives beyond the confines of their school settings.

\section{Living and Learning in the In-Between Through Unsanctioned Networks}

All participants expressed the importance of unsanctioned spaces where they found support during their teacher education and all alumni participants reiterated this need in their first years of teaching. They discussed how they built networks with peers and colleagues to resist external forces that went against their commitments to social justice. Reflecting on ECE/SJE spaces, one participant described:

I feel safe in these spaces. I don't feel as welcomed in other spaces, like "you are not white," or "you're exotic." That makes me feel uncomfortable. When I'm in [ECE/ SJE] faculty offices, I feel comfortable. This is really hard to find on campus, and I just need a space where I can just think and be.

Another participant discussed exploring critical theory with roommates in ways that they did not find in general university courses:

My suitemates were 6 women of color, many of whom were in SJE. I ended up in spaces where these topics were talked about casually. It didn't have to be a conference, it was just always talked about. In [university] classes, it was always apparent that I was the only POC [person of color] in the room. So in places where we would go more in depth, I felt I learned more because other people would share their opinions and my ideas would be challenged and I'd have to go do more research for myself. 
This participant made clear the importance of a network of women of color, several of whom were in the SJE minor, for deepening their consciousness when the standardization of teacher education was not working to develop critical thinking. Peers of color from across academic concentrations brought critical and varying perspectives that challenged the participant to consider the complexities of teaching within a racialized context. Citing the significance of learning experiences outside of campus courses, this participant noted the importance of SJE peers in their development of critical literacies of social justice.

The opportunity created at the intersection of SJE and ECE also provided opportunities for candidates to practice social justice within school contexts. One participant stated, "There is a lot of cross-over in curriculum content. ECE really listens to SJE. In preschool internship I really felt the connection. The entirety of preschool internship was about social justice and environmental justice and the ways we interact with children to support these beliefs and directions." Expanding on the internship as a point of significance, this teacher candidate stated, "It's the difference between theory and practice. I can read all this information but couldn't truly make sense of it until I experienced it first-hand."

Taken collectively, participants found their own spaces to develop into the kind of educators they desired to become when systems of $\mathrm{P}-12$ and teacher education did not provide for it. These in-between spaces allowed them to experiment with radical concepts and pedagogies in the classroom, as an effort to realize teaching as a transformative profession, despite the limitations of standardization and other neoliberal enactments affecting the daily life of schools. These in-between spaces became vital in supporting their attempts to nurture children's development toward a more socially just future, which we explore next.

\section{Nurturing Fugitive Futurities}

Participants consistently referenced the field of ECE, with a lens of SJE, as a space to foster an improved future for generations to come. One recent graduate reflected on the ways they drew from ECE and SJE:

I was in SJE, so trying to decolonize all of that and protecting children is social justice, trying to make a world where children can be free and willing to play and enjoy their lives. SJE helped me take apart the schools and how they worked and ECE focused on children and families and creating communities. So, schools aren't the best but how can we as ECE or SJE professionals make that better?

Another participant depicted concrete ways in which they applied the ECE/SJE course content toward addressing social issues during preschool internship. This participant emphasized that in working toward a reality we do not yet know, educators must be satisfied in small steps toward progress as we will not achieve dreams of decolonization within a single unit of study:

My project was about insects and bugs, but the thread was really about inclusion in our society. The children interacted with the big idea that insects and bugs are different but inherently the same with an underlying thread that we can all "play together." 
Sometimes you don't see the outcome but embracing the small positive moments where young children can grasp the big ideas, like inclusivity.

The participant then discussed the apprehension felt in implementing critical and decolonizing pedagogies through an inquiry unit. They depicted the difficulties faced when trying new approaches in teaching, but also the need to "trust the process" in order to reach goals as a critical educator. The participants in this study were consistent in holding hope for a better world, even if they may not see the results of their efforts. This was depicted clearly when one alumni participant considered how their younger sister may benefit from this work: "if I think about it I just want to give up. But if I think long term, I think about my sister. She's only 5 . What could happen by the time she gets to college?"

Participants also discussed the field of ECE as under-resourced, identifying the imbalance in school funding structure and considering the kind of educator they wanted to be. A participant stated:

I felt that in our society early childhood is not as valued as much as the other grades. There's just not enough money going into ECE, especially when you consider that so much learning goes on in the first five years of life. As a teacher of color, I want to be a face that other students could see themselves in early in life.

Participants frequently referenced the inequity in resource allocation across school settings, directly impacting one participant's decision to teach at a Title 1 school because it serves the most underserved students. These types of decisions to nurture futures for those most impacted by funding inequities and neoliberal policies was also informed by their own personal experiences. Participants discussed how their families and histories have impacted their goals and priorities as educators. One participant shared how the experiences as a student did not reflect community and familial ways of being. They considered how this would impact future students when candidates are prepared to teach academics alone:

I feel like I was prepared on how to teach the content, but I didn't have enough around how to connect and build relationships with students. Not just to look at them as children, but as humans. Being in a family-oriented culture you have to build relationships with people around you.

Another participant shared an in-depth reflection about how the internship challenged them to apply critical pedagogies in a context for which they were not yet prepared:

My student teaching definitely impacted me the most. When I look back at it, I think about deficit thinking toward historically marginalized students and students with trauma. I encountered a lot of students who experienced trauma and I didn't hold high standards for them, but then I had conversations with my ECE/ESJ professor about that. I couldn't baby them when they left school, so how could I foster that resiliency in school? I wanted to hold them rather than say I know you went through that, but I believe in you and you can do it. 
Through these findings, we see the participants viewing academic content as disconnected from fostering the holistic needs of children of color. By not centering such needs, classroom teaching does not work to improve the experiences for generations to come. Participants agreed that they held a responsibility to teach not only the required standards for academic success, but also to reimagine their roles and the context in which they plan to teach for social change. These efforts from within require a strategy to navigate systems and standards.

\section{Navigating Systems and Standards Strategically}

Participants demonstrated profound understandings of schools as systems grounded in settler-colonialism and White supremacy. They reflected deeply on their positionalities in schools and ways they work to make change. They described feeling a tension of when to speak up and offered examples of how they have engaged within structures of power. Participants also discussed where they felt confident in applying critical pedagogies and where they were prepared to make changes in curriculum. One participant shared:

Student teaching is like culture shock. It feels different when you are in the field and the [cooperating teacher] is talking about the "difficult child" or the "low child" and the way that they are framing things is very negative. But I am also challenged to confront veteran teachers. I mean this is not my classroom, it's not my school. I'm being aware of how they are using antiquated terms, and it's very different from what I believe and how I've been taught.

Participants also shared how they are attempting to work within neoliberal frameworks of education. One participant discussed their strategy for employing inquiry-based pedagogies within a standards-based curriculum:

Going into ECE, I wondered how do you do standards with young children? But now I see the alignment. You can do creative work and meet state standards. You have to really understand the standards to provide experiences for students to get to those standards but doing so through play. I want to follow the children's interests within a curriculum and I also understand that schools adopt a curriculum and that is what you have to teach. My hope is that there will be flexibility in the curriculum to support children's interest.

Participants also described their experiences navigating a complex system as a process of always becoming. They discussed how they made sense of standards in their planning and instruction and described complexity in their efforts to meet children's needs while aligning with school expectations. One participant depicted a commitment to transforming school-based education as a responsibility:

It is my job to push back against the system. You have to be in the system to work against it, work against a cycle that has been in place for centuries. Transformative educators will get pushback when they choose curriculum that reflects their students or practice pedagogies that are non-traditional, like inquiry-based pedagogies, and learning with their students. I learned through preschool internship that it is possible. To be a transformative teacher, you need to put your students first and stop the "wheel." 
As participants grappled with their work in teaching for social justice, within a standardized system of education, they came to understand how power and positionality maintained a neoliberal curriculum. They reflected on navigating such a system and where they found moments to challenge whitestream narratives and pedagogies. While these instances were few and far between, they offer small steps forward in moving away from standardization.

\section{Conclusion and Implications}

Given the standardization of U.S. public education, teachers must be prepared to respond critically in their work with young children and families. Acknowledging that standards impact all children and families, beginning with infants and toddlers, a need to understand how early childhood educators are working to surpass standardization and implement critical and decolonizing pedagogies is urgent. This study offers insight into how two programs came together to address this need and presents outcomes about the impact of said efforts on teacher practice. We centered the voices of teachers and teacher candidates, who face daily the difficult reality of a standards-based and test-driven school curriculum. Hearing from them about how they have navigated these structures to implement critical and inquiry-based pedagogies, and how two programs supported one another in developing critical educators, holds implications for the greater realm of teacher education.

Experiences shared about rejecting standardization and finding spaces where participants could "just be" offer insights into how critical educators are finding and creating support networks. Unsanctioned spaces offered opportunities for educators to experiment with strategies of fugitivity, where they could dream of systems that accepted their ways of knowing and being and practice implementing approaches where children's whole selves were represented and welcomed in the classroom. If we, in teacher education, along with teachers and administrators in schools, can hear from the participants the significance of teaching and learning as a relational experience and, like these participants, view meaningful relationships as an essential precursor to delivering instruction, we can begin engaging in the radical reform efforts needed to reclaim education through schooling (Stovall, 2018). We argue that this notion of fugitivity is an in-between space, a process toward the postcolonial rather than the end in and of itself. Along with the participants in this study, we dream a future where children are accepted for who they are and engage positively in playful, inquiry-based education.

That said, it cannot be ignored that the participants in this study were primarily teachers of color. These dreams of the postcolonial will not manifest through the continued preparation of primarily white educators. Neoliberal standardization will continue when classrooms are led by whitestream educators. We believe only when this norm is disrupted that change can occur. While not depicted as simple or easy, the teachers of color in this study offered a glimpse of what can change in schooling when the workforce is diversified and when educators are supported in their preparation to engage with critical theories. It was clear that their lived experiences changed the ways they engaged with children and families. Increasing the numbers of teachers of color alone would disrupt the standardization of education. It was made evident by the data that these participants need higher education 
to break the cycle of standards-based preparation. If we can learn from this research, and ground teaching and learning at all levels in love, relationship, and inquiry, then we begin a process of change toward a more meaningful education for all.

\section{References}

Apple, M. W. (2011). Global crises, social justice, and teacher education. Journal of Teacher Education, 62(2), 222-234. doi:10.1177/0022487110385428

Au, W., Bigelow, B., Burant, T., \& Salas, K. D. (2005). Action education: Teacher organizers take quality into their own hands. Rethinking Schools, 20(2), 11-14.

Battiste, M. (2004). Animating sites of postcolonial education: Indigenous knowledge and the humanities. Winnipeg, Manitoba: CSSE Plenary. May 29.

Cochran-Smith, M. (2004). Walking the road: Race, diversity, and social justice in teacher education. New York, NY: Teachers College Press.

Freire, P. (1973). Education for critical consciousness (Vol. 1). London: Continuum.

Giroux, H. A. (2003). Critical theory and educational practice. In A. Darder \& M. Baltodano (Eds), The critical pedagogy reader. New York, NY: RoutledgeFalmer.

Harney, S. M., \& Moten, F. (2013). The undercommons: Fugitive planning and Black study. Wivenhoe, UK: Minor Compositions.

Haslip, M. J., \& Gullo, D. F. (2018). The changing landscape of early childhood education: Implications for policy and practice. Early Childhood Education Journal, 46(3), 249-264. doi:10.1007/s10643-017-0865-7

Heineke, A., Kennedy, A., \& Lees, A. (2013). Preparing early childhood teachers for the culturally and linguistically diverse classrooms of Illinois. Early Childhood Research and Practice, 15. Available at http:/ /ecrp.uiuc.edu/v15n2/heineke.html

la paperson (2017). A third university is possible. Minneapolis, MN: University of Minnesota Press.

Lees, A., \& Kennedy, A. (2017). Community-based collaboration for early childhood teacher education: Partner experiences and perspectives as co-teacher educators. Journal of Early Childhood Teacher Education, 38(1), 52-78. doi:10.1080/10901027.2016.1274692

Merriam, S. B., \& Tisdell, E. J. (2015). Qualitative research: A guide to design and implementation. San Francisco, CA: Jossey-Bass.

National Association for the Education of Young Children (2009). Developmentally appropriate practice in early childhood programs serving children from birth through age 8: A position statement of the National Association for the Education of Young Children. Washington, DC: National Association for the Education of Young Children.

National Association for the Education of Young Children (2010). 2010 NAEYC standards for initial \& advanced early childhood professional preparation programs. Retrieved from www.naeyc.org

National Association for the Education of Young Children (2015). Developmentally appropriate practice and the common core state standards: Framing the issues. Washington, DC: National Association for the Education of Young Children.

National Commission on Excellence in Education (1983). A nation at risk. Washington, DC: U.S. Government Printing Office.

Noddings, N. (2005). What does it mean to educate the whole child? Educational Leadership, 63(1), 8-13. 
Smith, L. T. (2013). Decolonizing methodologies: Research and indigenous peoples. London, UK: Zed Books.

Stovall, D. (2018). Are we ready for 'school' abolition?: Thoughts and practices of radical imaginary in education. Taboo: The Journal of Culture and Education, 17(1), 6. doi:10.31390/ taboo.17.1.06

Tuck, E., \& Gaztambide-Fernández, R. A. (2013). Curriculum, replacement, and settler futurity. Journal of Curriculum Theorizing, 29(1), 72-89.

Tuck, E., \& Yang, K. W. (2012). Decolonization is not a metaphor. Decolonization: Indigeneity, Education E Society, 1(1), 1-40.

Yin, R. K. (2017). Case study research and applications: Design and methods. Thousand Oaks, CA: Sage Publications. 